\title{
Mass mortality of the tropical seagrass Thalassia testudinum in Florida Bay (USA)
}

\author{
M. B. Robblee ${ }^{1}$, T. R. Barber ${ }^{2}$, P. R. Carlson, $\mathrm{Jr}^{2}$ \\ D. Porter , L. A. Yarbro ${ }^{2}$, R. T. Zieman ${ }^{3}$, J. C. Zieman ${ }^{3}$ \\ ' Everglades National Park, South Florida Research Center, Homestead, Florida 33030, USA \\ ${ }^{2}$ Florida Marine Research Institute, 100 Eighth Avenue SE, St. Petersburg, Florida 33701, USA \\ ${ }^{3}$ University of Virginia, Department of Environmental Sciences, Charlottesville, Virginia 22903, USA \\ ${ }^{4}$ Caribbean Research Institute, University of the Virgin Islands, St. Thomas 00802, U.S. Virgin Islands \\ ${ }^{5}$ University of Georgia, Department of Botany, Athens, Georgia 30602, USA
}

ABSTRACT. This report documents rapid and widespread mortality of the seagrass Thalassia testudinum Banks ex König (turtle grass) in Florida Bay at the southern tip of the Florida peninsula (USA). More than 4000 ha of seagrass beds have been completely lost in recurring episodes of mortality since summer 1987 An additional 23000 ha have been affected to a lesser degree. Loss of $T$. testudinum, the dominant macrophyte species in this highly productive system, may affect ecosystem function within the bay as well as estuarine-dependent sport and commercial fisheries. A pathogenic protist related to the causal agent of the eelgrass wasting disease may be involved in the mortality and may place $T$. testudinum populations outside Florida Bay at risk Environmental factors and chronic hypoxia of below-ground $T$ testudinum tissue may also contribute to the die-off.
Florida Bay is a shallow, triangular lagoon at the southern tip of peninsular Florida bordered on the north by the Florida mainland and on the southeast by the Florida Keys; its western margin is open to the Gulf of Mexico. Shallow carbonate mud banks divide the bay into basins, restrict circulation, and attenuate the Gulf's lunar tidal influence. Freshwater enters the bay in the northeast from Taylor Slough, as overflow from the C-111 Canal that is part of the South Florida Water Management District's canal system, and as sheet flow generated by local rainfall. Depending on the timing and amounts of local rainfall, water conditions in the

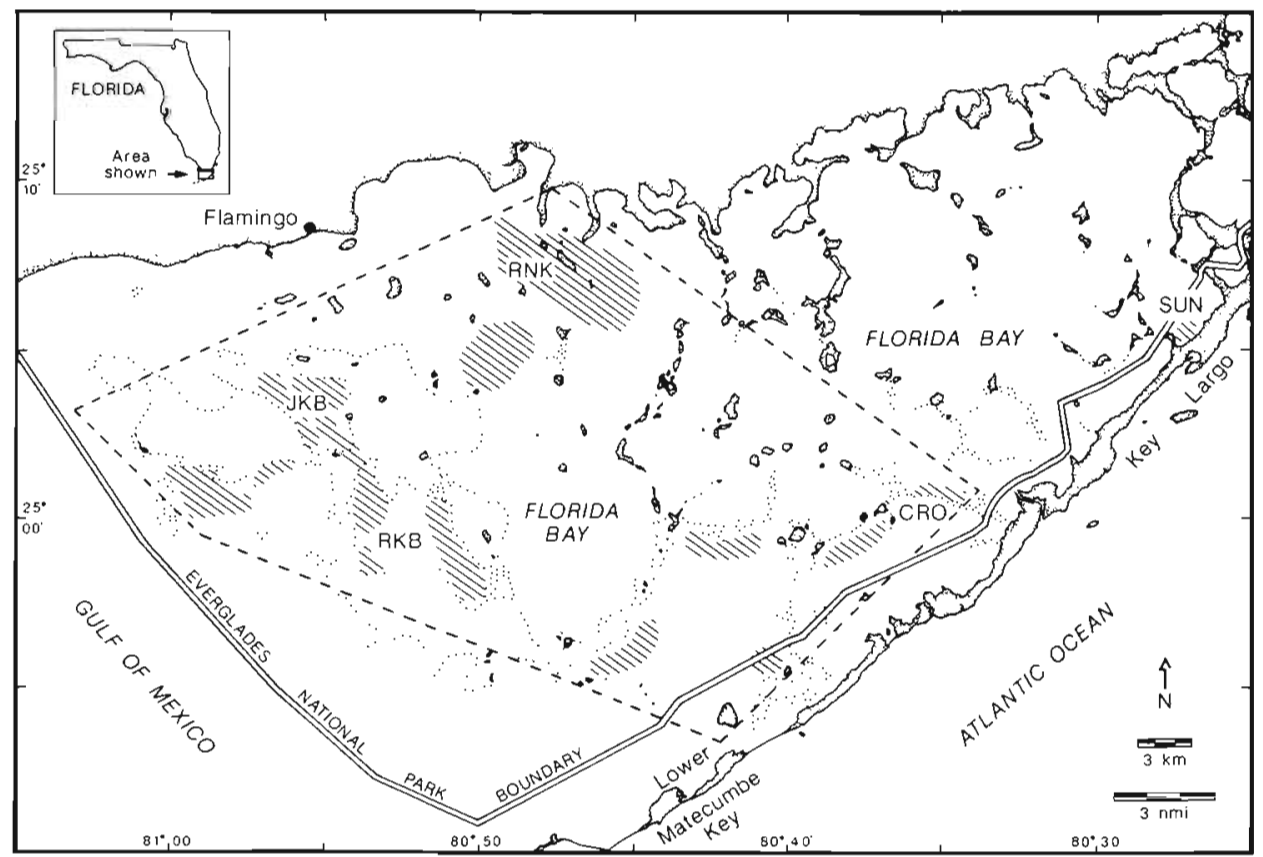

Fig. 1. Distribution of Thalassia testudinum dieoff in Florida Bay. Continuous double line is Everglades National Park boundary. Dashed line encloses most known die-off areas. Hatched areas are severely affected, having lost up to $95 \%$ of $T$. testudinum. Dotted lines mark shallow carbonate mud banks. JKB Johnson Key Basin; RKB: Rabbit Key Basin; RNK: Rankin Lake; CRO: Cross Bank; SUN: Sunset Cove 
bay oscillate between brackish and hypersaline. Restricted circulation in the bay resuits in environmental and biological gradients along a southwest to northeast transect (Schomer \& Drew 1982, Tilmant 1989). Zieman et al. (1989) have determined that seagrasses cover more than $80 \%$ of the $1800 \mathrm{~km}^{2}$ area of Florida Bay within the Everglades National Park boundaries.

Loss or changes in species composition of seagrass habitat may affect many economically important fish and shellfish species. Over 100 species of fishes and over 30 crustacean species are found in Florida Bay, including both permanent residents and temporary residents which use seagrass habitat as a nursery ground, such as spotted seatrout, redfish, snook, tarpon, snappers, and grunts. Important shellfish species include pink shrimp (Penaeus duorarum Burkenroad) from the Tortugas bank, blue crabs, and spiny lobsters (Tabb et al. 1962, Allen et al. 1980, Klima et al. 1986. Thayer \& Chester 1989).

Dead and dying Thalassia testudinum were first observed near Cross Bank and in Rankin Lake during summer 1987 (Fig. 1). By summer 1988, die-off was evident in ca $30 \%$ of the dense seagrass beds of western Florida Bay. An extensive Thalassia bed in Sunset Cove, some distance from other sites but adjacent to the Everglades National Park boat dock, died between November 1988 and January 1989. At present, die-off continues to spread within the areas where it was initially observed, and has been reported from

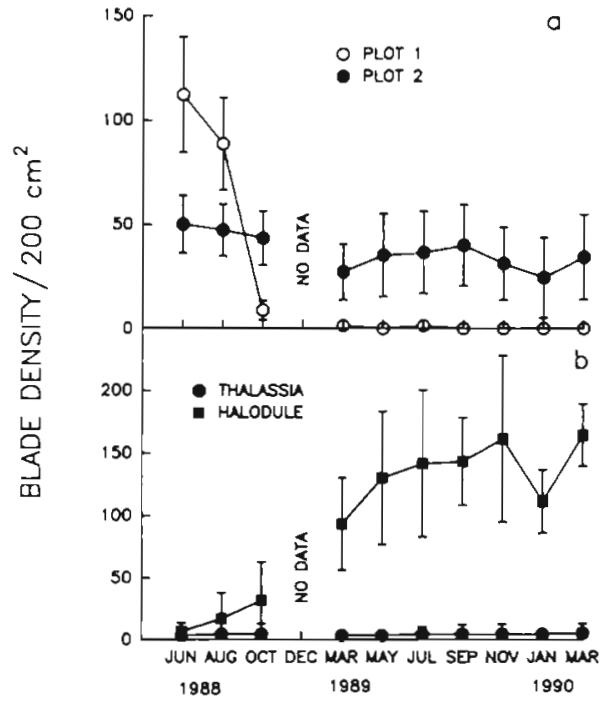

Fig. 2. (a) Leaf blade density of Thalassia testudinum at 2 monitoring 'plots' in Johnson Key Basin. Data are mean blade density in 8 replicate $200 \mathrm{~cm}^{2}$ quadrats ( $\pm 1 \mathrm{SD}$ ). (b) Recolonization of die-off patches in a nearby plot by Halodule wrightii

new areas in the southern half of Florida Bay. Dense Thalassia beds within protected basins appear to be most severely affected by die-off. The depth of affected seagrass beds varies widely, but most die-off patches are located in shallower portions $(<1.5 \mathrm{~m}$ below mean sea level) along the margins of basins.

Die-off occurs most rapidly during fall and spring. At one 'plot' in Johnson Key Basin where divers count
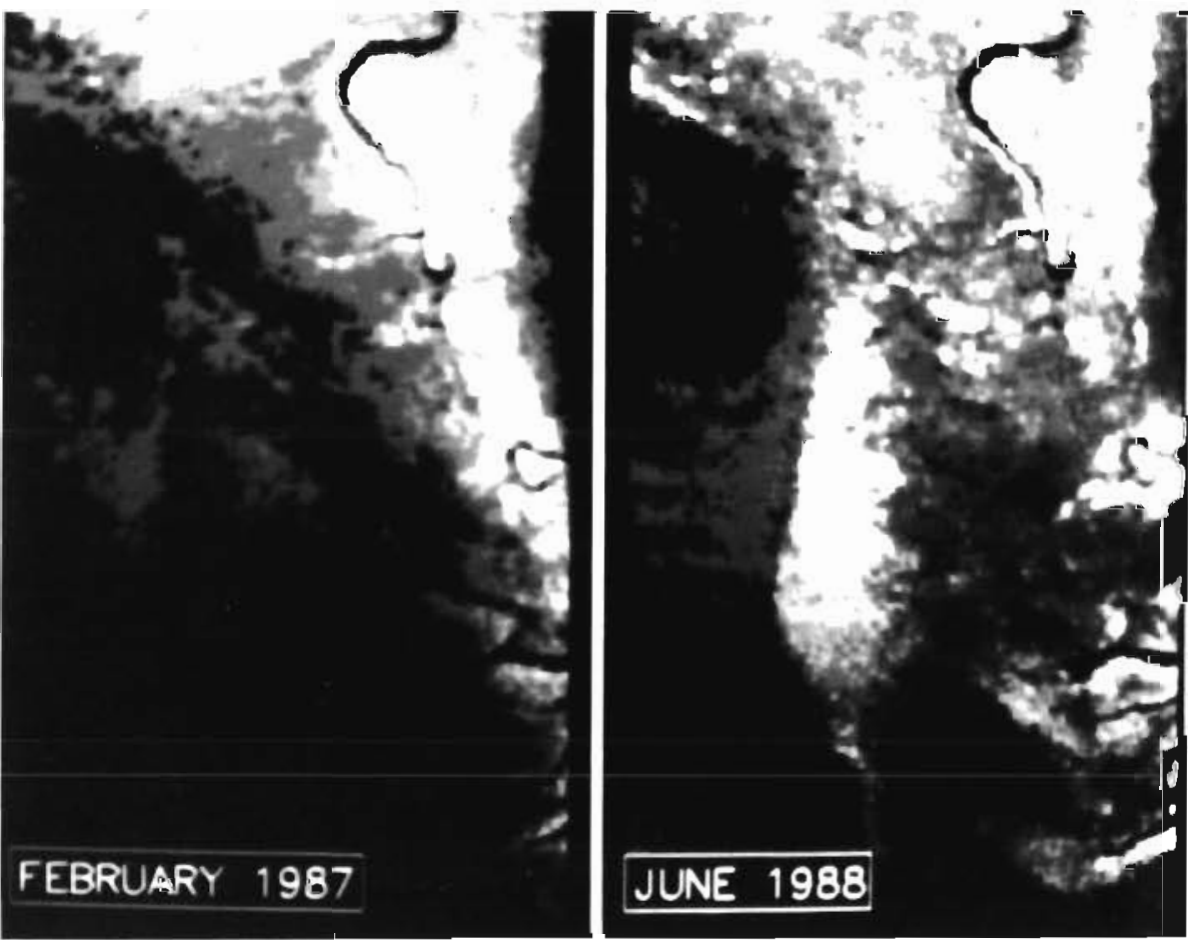

Fig. 3. Thalassia testudinum. Expansion of die-off patches in eastern Rabbit Key Basin estimated from SPOT satellite imagery between February 1987 and June 1988. Dimensions of each frame are $2.2 \mathrm{~km}(\mathrm{E}-\mathrm{W}) \times 3.4 \mathrm{~km}(\mathrm{~N}-\mathrm{S})$ Light areas represent sparse coverage dark $_{\text {areas }}$ represent dense coverage. See text for further description 
seagrass shoots in permanent quadrats, Thalassia testudinum completely disappeared between August and October 1988, while a nearby plot was unaffected (Fig. 2a). Because T. testudinum is much more abundant in affected areas than Halodule wrightii Aschers. or Syringodium filiforme Kutzing, the susceptibility of these latter species is not known. The rapid increase of $H$. wrightii shoot density seen in the nearby plot and other die-off patches suggests that it might outstrip $T$. testudinum in the initial phases of recovery (Fig. 2b).

The size of die-off patches varies within and among basins. The development of a large (63 ha) die-off patch in eastern Rabbit Key Basin between February 1987 and June 1988 is shown in Fig. 3. In these satellite (SPOT) photographs, the white area in the upper right one-third of the picture area is shallow 'bank' habitat covered by sparse Thalassia testudinum. Two islands, the Rabbit Keys, are visible along the right (east) margin of each frame. The February 1987 photograph shows fairly uniform, dense coverage of seagrass (represented by dark areas) in the lower left two-thirds of the picture area, although the initial nucleus of the die-off patch is visible as a lighter gray region in the center of the upper third of the earlier photo. The June 1988 photo shows complete mortality of $T$. testudinum from an elliptical region, ca $1.9 \mathrm{~km}$ long, in the center of the photograph.

The recurring episodes of rapid, but patchy, mortality are very different from the gradual loss of seagrass due to eutrophication reported in other estuaries (Kirkman 1976, Kemp et al. 1983, Cambridge \& McComb 1984). Because die-off is occurring in areas far removed from surface-water pollution sources (Fig. 1), anthropogenic contaminants are probably not involved. Abnormally high water temperature, recent reduced frequency of hurricanes, high salinity, a pathogenic slime mold (Labyrinthula sp.) related to the causative agent of eelgrass wasting disease (Short et al. 1987, Muehlstein 1989), and chronic hypoxia of Thalassia testudinum roots and rhizomes are potential causes of the phenomenon which are currently under investigation. Without clear demonstration of causal factors, however, we cannot predict the rate of spread, the long-term recovery potential of affected areas or the geographical limits of T. testudinum populations at risk.

This note was presented by $\operatorname{Dr} G$. W. Thayer, Beaufort, N. Carolina, USA
Acknowledgement. Preliminary and ongoing work has been funded in part by Cooperative Agreement OA-5280-9-8002 from the US Department of the Interior, National Park Service, Everglades National Park, in part by Project F-44 from the Department of the Interior, US Fish and Wildlife Service, Federal Aid for Sportfish Restoration, and in part by funds provided by the Florida Department of Environmental Regulation, Office of Coastal Management, using funds made available through the National Oceanic and Atmospheric Administration under the Coastal Zone Management Act of 1972, as amended.

\section{LITERATURE CITED}

Allen, D. M., Hudson, J. H., Costello, T. J. (1980). Postlarval shrimp (Penaeus) in the Florida Keys: species, size, and seasonal abundance. Bull. max. Sci. 30: 21-33

Cambridge, M. L., McComb, A. J. (1984). The loss of seagrasses in Cockburn Sound, Western Australia. I. The time course and magnitude of seagrass decline in relation to industrial development. Aquat. Bot. 20: 229-242

Kemp, W. M., Twilley, R. R., Stevenson, J. C., Boynton, W. R., Means, J. C. (1983). The decline of submerged vascular plants in upper Chesapeake Bay: summary of results concerning possible causes. J. mar. technol. Soc. 17: 78-85

Kirkman, R. H. (1976). A review of the literature on seagrass releated to its decline in Moreton Bay, Qld. CSIRO Rep. No. 64

Klima, E. F., Matthews, G. A., Patella, F. J. (1986). Synopsis of the Tortugas pink shrimp fishery, 1960-1983, and the impact of the Tortugas sanctuary, N. Am. J. Fish. Man. 6: 301-310

Muehlstein, L. K. (1989). Perspectives on the wasting disease of eelgrass Zostera marina. Dis. aquat. Org. 7: 211-221

Schomer, N. S., Drew, R. D. (1982). An ecological characteristization of the lower Everglades, Florida Bay and the Florida Keys. U.S. Fish Wildl. Serv. Publ. FWS/OBS-82/58

Short, F. T., Muehlstein, L. K., Porter, D. (1987). Eelgrass wasting disease: cause and recurrence of a marine epidemic. Biol. Bull. mar. biol. Lab., Woods Hole 173: $557-562$

Tabb, D. C., Dubrow, D. L., Manning, R. B. (1962). The ecology of northern Florida Bay and adjacent estuaries. Florida Board of Conservation Technical Series No. 39, St. Petersburg, Florida

Thayer, G. W., Chester, A. J. (1989). Distribution and abundance of fishes among basin and channel habitats in Florida Bay. Bull. mar. Sci. 44: 200-219

Tilmant, J. T (ed.) (1989). Proceedings of the Symposium on Florida Bay. Bull. mar. Sci. 44 (1)

Zieman, J. C., Fourqurean, J. W., Iverson, R. L. (1989). Distribution, abundance and productivity of seagrasses and macroalgae in Florida Bay. Bull. mar. Sci. 44: 292-311

Manuscript first received: November 19, 1990

Revised version accepted: February 22, 1991 